\title{
Judges Under Stress: Understanding Continuity and Discontinuity of Judicial Institutions of the CEE Countries
}

\author{
Hans Petter Graver ${ }^{1}$ and Peter Čuroš ${ }^{1}$ (D) \\ ${ }^{1}$ Institute of Private Law, University of Oslo, Oslo, Norway and Institute for Private Law, University of Oslo, \\ Oslo, Norway \\ Corresponding author: peter.curos@jus.uio.no
}

(Received 06 October 2021; accepted 06 October 2021)

\section{A. Introduction}

The project Judges under Stress aims to elaborate on a more in-depth understanding of the historical process that is often covered by the "grand narratives." These are commonly built on the notions of old institutionalism focusing on formal institutions, providing clear-cut, stable, rigid, unquestionable versions of the past. Our quest is to dismantle these narratives.

The grand narratives lack the understanding that the countries' transition may not depend solely on a change of formal rules. They focus on important events, ruptures, during which the formal framework changes. However, the change may be rooted in a shift of informal norms, personnel, tradition, and culture. Narratives are easy to follow; they are likely to be heard and easily retold. They are often described in a limited scope because of the hesitance of taking a challenge to consider all the social development, everyday life, ideology, resistance, obedience, legislature, common sense, academic works, and other factors. Therefore, the narratives are often told periodically, as one block of events, chronologically coming after another, distinguished only by a beginning and an end. However, our project would like to doubt rigid concepts of beginnings and ends. What often might be considered a start of some era may be a continuation of the previous process and previous decisions from limited possibilities of past choices.

An institution is a crucial concept. It is a structure, a web of events, decisions, knowledge, rules, traditions, habits, morals that form social life. Douglass North defines institutions as "humanly devised constraints that structure political, economic and social interaction." Institutions define roles, relations, and powers. People fill these positions and thereby form organizations. Moreover, in institutions, we may find more intricate structures that explain reality in a more detailed, verifiable, and reliable way. Deconstruction of the institution may show us, for example, that what might be a significant rupture in the political sphere of social reality, might still be represented by continuity in the field of personnel of state administration or habitus of the members of the group that contradicts the aims of the formal rules. While the grand narratives focus on discontinuities of formal rules, the informal continuities stay often overseen.

We decided to deconstruct these narratives and verify them with knowledge of the past and extensive archival work. Our project aims to research the specific events, policies, and

This special issue emerged from the project Judges under Stress - The Breaking Point of Judicial Institutions Project. The project is financed by the FRIPRO program of the Norwegian Research Council and the University of Oslo (2019-2022).

${ }^{1}$ Douglass C. North, Institutions, 5 J. ECON. Perspectives 97, 97 (1991). 
development of the institutions, focusing on the judiciary. We follow judiciaries within the Central and Eastern European (CEE) countries to point out resemblances with the authoritarian past. After implementation of the democratic policies post-1989 and claimed ambition to the rule of law by the CEE countries, there must be something typical for this group of countries that hinders the democratic transition and settlement of the institutions that would limit the parliaments or administration and establish the stable guarantees such as the strong and independent judiciary.

The project aims to be cross-disciplinary, bold, and innovative in studying the functioning of the judiciary in its combination of a historical, comparative, and legal method in comparing judges under authoritarian conditions across different legal traditions with an institutional approach. A historical comparison across different traditions allows us to provide an analytical framework that allows critical assessments of how rulers seek to influence and control judges. Considering today's Central and Eastern European countries, some courts face powerful political forces calling for illiberal measures. In this situation, it is vital to have more knowledge and a better understanding of how judicial institutions react under stress and why they react that way.

In the Central and Eastern European countries, the focus on the period between 1939-1989 may help us by taking new points of view of the development of the judiciary today. Moreover, it may explain the difficult transition in these countries towards the rule of law, why institutions like the judiciary enjoy such low trust from the public, and why they experience backsliding tendencies toward authoritarianism. In other words, why the change of formal rules at the end of state socialism did not bring the expected long-term outcomes, and the countries of the CEE examined here face the wave of authoritarian politics today.

The relevance is embedded in the comparative approach of the development of judicial institutions in five of the CEE countries, which are also member states of the EU-Poland, Hungary, Czech Republic, Slovakia, and Romania. Thanks to experts from academia and practice in these countries, we can provide a valuable comparative outcome. The participants of the research seminar in Oslo are the representatives of the universities, either in the CEE countries or abroad (Norway, UK, US), recent or former judges, and clerks at constitutional courts, lawyers, and public activists. This choice of the participants allowed us to have an outcome with comprehension of various backgrounds.

In the following lines, we will present the main concepts on which the approach of this Special Issue builds. First, we explain the concept of an institution, second, the terms continuity and discontinuity, and third, the path dependence. Finally, individual contributions will be introduced.

\section{B. Theoretical Approach}

\section{Institutional Approach and Institutions}

In the limelight of our focus stands informal practice-actions within institutions determined by the informal institutional framework. Several theoretical perspectives are possible when explaining human action. Action can be norm-driven and conventional, strategic and governed by the interests of those actions, or determined by relations of power and dependence. An institutional approach combines all these, as institutions provide opportunities, constraints, and incentives and form the basis for establishing and maintaining power relations. Moreover, the institutional approach focuses on the structure reflected by technical demands and resource dependencies and on institutional forces, including rational myths, legitimating knowledge through the educational system, professions, public opinion, and the law. ${ }^{2}$ The institutional approach assumes that positions within organizations matter more than the agents who occupy them. The axiom enables us to discuss roles than particular people. The agents within institutions are not considered essential

${ }^{2}$ Paul J. Dimaggio \& Walter W. Powell, The New Institutionalism in Organizational Analysis (1991). 
because their interests are tied up with their position in the institution. Institutions shape their action because they mold their behavior. In other words, the institutional approach is interested in how institutions function, affect each other and affect subjects within them. The institutional approach seeks to understand the historical, organizational, and structural features of the action within an institution and how it becomes constituted. This approach is used in legal theory, ${ }^{3}$ history, and sociology ${ }^{4}$ and is also used in economics, ${ }^{5}$ psychology, ${ }^{6}$ and organizational analysis. ${ }^{7}$

It does not mean, however, that actors and agency are unimportant. Decisions matter, but decisions are influenced by institutions. People and organizations are brought into an institutional matrix and resist changes that affect their position and interests. The belief system underlying an institutional matrix also deters radical change. Institutions give shape to beliefs, values, and the development of knowledge. According to North, "the whole structure that makes up the foundation of human interaction is a construct of the human mind and has evolved over time in an incremental process; the culture of a society is the cumulative aggregate of the surviving beliefs and institutions."

\section{Continuities Within Discontinuities}

A popular way to organize the past is by periodization. It seems natural to put the events that happened within the same time together. Periodization means dividing history into blocks, where the elements in these blocks have in common that they are characteristic by a principle that defines their place in the box. It establishes grounds for coherence and objective inquiry in history. ${ }^{9}$

Periodization is also helpful for creating identities — characterizing an object by one or several qualities that define the object (determination of the object for the sake of our perception). It leads to analyzing the phenomenon detached from other objects. Periodization is thus helpful for perceiving the phenomenon-happening within the sequence. ${ }^{10}$

Periodization, as a method, can help divide the past into stages. However, when it is the only applied method, it leads to reductionism. Limiting ourselves to periodization limits the options we use to think about an institution. Similar to Thomas Kuhn, who describes the scientific revolutions, periodization is often used in the same way as a paradigm works in natural sciences, as the limited scope of views that are recognizable and applicable at a particular time in a particular space. ${ }^{11}$

Any periodization scheme is or implies a schedule of priorities. It is or implies a set of generalizations which order the infinite of available data, and provide some clues as to their significance. Ultimately, the periodization scheme permits telling of a causal story about collective human affairs could not be told without it . . . But there are many possible stories one might tell. ${ }^{12}$

\footnotetext{
${ }^{3}$ See Ota Weinberger, Law, Institution and Legal Politics: Fundamental Problems of Legal Theory and Social Philosophy (1991). Neil MacCormick, An Institutional Theory of Law: New Approaches to Legal Positivism (1986).

${ }^{4}$ As Emile Durkheim calls sociology to be the science of institutions.

${ }^{5}$ See Douglass C. North, Understanding the Process of Economic Change 133 (2005).

${ }^{6}$ See Serge Moscovici, The Origin of Social Representations: A Response to Michael, 8 NEW IDEAS IN PsYCH. 383 (1990).

${ }^{7}$ Ronald L. Jepperson, Institutions, Institutional Effects and Institutionalism, in THE NEW InsTITUTIONALISM IN Organizational Analysis 143 (Paul J DiMaggio \& Walter W. Powell, eds. 1991).

${ }^{8}$ NORTH, supra note 5 , at 83.

${ }^{9}$ Martin J. Sklar, Periodization and Historiography: Studying American Political Development in the Progressive Era, 1890s-1916, 5 Stud. AM. Pol. Dev. 173 (1991).

${ }^{10}$ Karen Orren \& Stephen Skowronek, 4. Institutions and Intercurrence: Theory Building in the Fullness of Time, in Political Order 111, 116 (New York Univ. Press, 1998). "By relating order to time, periodization schemes lay a foundation for theorizing about the role of temporality in political life."

${ }^{11}$ Thomas S. Kuhn, The Structure of Scientific Revolutions (2012).

${ }^{12}$ Walter Dean Burnham, Periodization Schemes and "Party Systems": The "System of 1896" as a Case in Point, 10 Soc. SCI. HisT. 263 (1986).
} 
Even if we apply simple periodization on the periods before and after the period in focus, we will see only pictures of the institution, which follow one after another, just like an old film looked like - motion pictures, which need to follow in the detailed elaboration of detail on change, at the very particular pace - to make us understand what is going on the screen.

Therefore, it is necessary to apply a transition to cross the abyss between separate pictures. While the individual pictures enable us to see how the institution looked at a particular moment, they do not show us how the change happened. To see this change, it is necessary to identify currents within the institution and look for their historical evolution - in diachrony ${ }^{13}$ within synchrony. ${ }^{14}$

Periodization prioritizes discontinuities, the precise cuts in history, where the beginnings and ends are identifiable. However, our quest is to focus on the persisting continuities in the institution despite the formal discontinuity.

By discontinuity, we mean a moment of rupture-when a new element appears within the set of social communication-which was not part of the social communication system before. For example, take the socialist law in CEE countries when new elements were implemented after 1945-such as the leading role of the Communist Party and socialist legality. Continuity represents a pattern that exists despite the crucial social or political change, the patterns persisting in the institution from the time before formal discontinuity. The continuities are often persisting within the informal practice as

the habitus, the product of history, that produces individual and collective practices, and hence history, in accordance with the schemes engendered by history. The system of dispositions - a past which survives in the present and tends to perpetuate itself into the future by making itself present in practices structured according to its principles, an internal law relaying the continuous exercise of the law of external necessities - is the principle of the continuity. ${ }^{15}$

Therefore, we look for the approach that could dismantle the event to particular currents that lead to the event itself and look for the outcomes and continuities of these particular currents later. These outcomes do not necessarily reveal themselves immediately but may evolve within the informal practices and become crucial for institutions much later.

It is not a single current explaining why the phenomena in this current led to the outcome that we could empirically perceive. It is not a single current that could be interrupted by a sudden change. Instead, a multitude of currents relate to each other at one or several points and interact. Within the institution, we can observe various currents which may develop at the same pace. However, it is more likely that they are developing at different paces. When the contradiction within two or more currents is too significant, it has consequences-in the form of a critical juncture. Capoccia and Kelemen present critical junctures as punctuations of stability. ${ }^{16}$ Often critical junctures are referred to in the literature as turning points, crises, or unsettled times. ${ }^{17}$

\footnotetext{
${ }^{13} \mathrm{~A}$ method, which focuses on the change-becoming, of the meaning and position of a phenomenon in social system in the past. The reader may observe this approach later in the chapter, as pointing on the evolution of the concept of political independence in the past.

${ }^{14} \mathrm{~A}$ method, in which we consider the meaning of a phenomenon in no connection to the past. We focus strictly on the placement of this phenomenon and relations to other phenomena in the social system. The reader may observe this approach in chapter on the conceptual analysis of the political independence of the lawyer and relation to other kinds of independence of the lawyer. This method is typical for linguistic analysis. See Ferdinand DE SAUSSURE, Course In GENERAL LinGUISTICS 96 (Philosophical Library 1959).

${ }^{15}$ Pierre Bourdieu, Outline of a Theory of Practice 82 (Reprint edition ed. 1977).

${ }^{16}$ Giovanni Capoccia \& R. Daniel Kelemen, The Study of Critical Junctures: Theory, Narrative, and Counterfactuals in Historical Institutionalism, 59 WORLD POL. 341, 341 (2007).

${ }^{17}$ Kathleen Thelen, How Institutions Evolve, in COMParative Historical Analysis in the Social Sciences (James Mahoney \& Dietrich Rueschemeyer eds., 2003). James Mahoney, The Legacies of Liberalism: Path DePendence And Political Regimes in Central America (2001). "[C]hoice point[s] when a particular option is adopted among two or more alternatives," defined by antecedent historical conditions. KARL Polanyi \& Robert Morrison MacIver, The Great
} 
The critical juncture is neither a spot nor a box on the timeline. Rather, the critical juncture is the period within which the institution evolves from tension within the institution itself and the tension among other institutions. A critical juncture is the period when contradiction among the several currents of the institution crosses the limit of the possibility of resolving the contradiction by a simple "returning to status quo." Their criticality is based on the effect on institutional arrangements, which are characteristic of stability and resiliency. ${ }^{18}$ Our interest in critical junctures is based on their nature-of periods when the particular currents surpass other and particular qualities of the institution continue, while other either disappear or survive on the level of the informal practice.

\section{Path Dependence}

Simply put, path dependence means that where we go next depends not only on where we are now but also upon where we have been. ${ }^{19}$ As Bourdieu claims, "In each of us, in varying proportions, there is part of yesterday's man; it is yesterday's man who inevitably predominates in us since the present amounts to little compared with the long past in the course of which we were formed and from which we result." ${ }^{20}$ In the same way, institutions bear their historical heritage. The main feature of institutional theory is path dependence, representing the constraining effects of past policy decisions on current and future policy and institutional arrangements. Path dependence is, according to North, "the way by which institutions and beliefs derived in the past influence present choices." ${ }^{21}$ We inherit the artefactual structure-the institutions, beliefs, tools, techniques, and external symbol storage systems - from the past. ${ }^{22}$ From a legal perspective, it points to how the existing conceptual structure and set of practices influence the approach to novel issues that are often tackled by analogy. ${ }^{23}$ The combination of such beliefs, institutions, and artefactual structure inherited from the past limits the actors' choices and imposes severe constraints on the ability to effectuate change. An essential part of path dependence is an "intimate relationship between belief systems and the institutional framework." ${ }^{4}$ This relationship constrains and empowers social actors, who in turn act to uphold their positions. Addressing the market structure, North accentuates that the structure reflects those in a position to make the rules of the game and those who enact the rules that will produce the outcomes. The relationship is evident in the formal rules but "is most clearly articulated in the informal institutions-norm, conventions, and internally held codes of conduct." 25 Path dependence is the heritage of institutions accumulated from the past, but it is also a result of organizations built on the institutions that will devote resources to prevent any alteration that threatens their survival.

Path dependence is more than just that "history matters." Choices that have been made in building institutions influence the future scope of action. A choice that has been embedded in a norm becomes the regular course of action. There is, however, another side of path dependence - the fact that it is difficult to exit from a path once the path has been laid. ${ }^{26}$ There may

Transformation (1944). Niles Eldredge, Punctuated Equilibria: An Alternative to Phyletic Gradualism, in Time Frames 193-224 (2014).

${ }^{18}$ James Mahoney, Path-dependent Explanations of Regime Change: Central America in Comparative Perspective, 36 STUD. COMPAR. INT'L DEv. 111, 114 (2001). “[O]nce a particular option is selected [in a critical juncture], it becomes progressively more difficult to return to the initial point when multiple alternatives were still available."

${ }^{19}$ Stan J. Liebowitz \& Stephen E. Margolis, Path Dependence, in ENCYClOPEDIA OF LAW AND ECONOMICS 981 (Gerrit de Geest ed., 1999).

${ }^{20}$ Bourdieu, supra note 15 , at 79 .

${ }^{21}$ NORTH, supra note 5 , at 21.

${ }^{22} I d$. at 156 (path dependence in a "narrower" sense).

${ }^{23}$ John Bell, Path Dependence and Legal Development, 87 Tul. L. REv. 787, 792 (2012).

${ }^{24}$ NorTH, supra note 5 , at 49.

${ }^{25} \mathrm{Id}$.

${ }^{26}$ Paul Pierson, Increasing Returns, Path Dependence, and the Study of Politics, AM. Pol. ScI. Rev. 251, 252 (2000). 
be sunk costs in the current pattern of action or establishing a new path may be costly. The difficulty of reversing a course may be even more difficult in politics than in economics. ${ }^{27}$ Finally, we have the constraint of ideas and beliefs; other ways of doing things are simply unthinkable, or the time and effort of thinking out new ways of doing things are discouraging.

\section{In Conclusion of the Approach}

Extended scholarship relates to non-compliance of formal institutions, seeking the rule of law, with persisting practice furthering contradicting interests. ${ }^{28}$ Michal Bobek explains non-compliance as institutional mimicking, when "new institutions are created, but the values and patterns of behavior which are necessary for the institution to function properly do not come with it." 29 Informal institutions might be central to resolving the issue of institutional changes not yielding the desired outcome. Institutions are enduring political and social life features that structure behavior and cannot be changed easily or instantly.

Institutions consist of the formal "rules of the game" and their enforcement, informal practices, and beliefs, often less visible or even unnoticed by actors inside and outside those institutions. ${ }^{30}$ Particularly, it is more challenging to change informal practices than formal rules because of the unnoticeable character of beliefs and patterns of social behavior outside formal rules. The informal practice persists as long it lowers players' transaction costs. ${ }^{31}$ In order to change the informal practice, the agent whose transaction costs of action via informal practice must be lower than the costs of action based on the formal rule limit. This agent's limitation is problematic if the agent is limited and strongly connected to the power responsible for enforcing formal rules. Thus, North states that "if the highest return in an economy is to piracy, we can expect that the organizations will invest in skills and knowledge that will make them better pirates." 32

It is this persistence of informal practice that hinders the expected social change. Moreover, it is ignorance of the informal practice that blocks understanding of this process. The simplification of the reality to formal institutions whose existence is defined by periods that start and end at a particular moment is dangerous. It is also dangerous to think that the change of the regulation at a particular moment will quickly change the behavior of the individuals within institutions. It is naive to expect that even the time will heal unwanted behavior patterns. It is interesting to watch how such a reaction was expected in past attempts, especially in radical social changes-for example, the attempt of the Communists to create a "socialist-type person" without the "burden of the past." Such a utopia could not be true, as the political system itself was still carrying its burden of the past with itself. This is also a memento for today's recognition of social reality. We could have seen the solutions of implementing structures in the political system which would further the rule of law in the post-communist countries. However, this process leads to new problems, as implants were not received in these countries with the efficiency expected by the EU and Council of Europe.

\footnotetext{
${ }^{27} \mathrm{Id}$. at 257

${ }^{28}$ Gretchen Helmke \& Steven Levitsky, Informal Institutions and Democracy: Lessons From Latin America (2006); Santiago Basabe-Serrano, Informal Institutions and Judicial Independence in Paraguay, 1954-2011, 37 LAW \& Pol'y 350, 353 (2015); BJÖRn Dressel, Raul SANCHEZ-Urribarri \& AleXANDER Stroh, Courts and INFormal networks: Towards a Relational Perspective on Judicial Politics Outside Western Democracies (2018); Åse B. Grødeland \& Aadne Aasland, informality and Informal Practices in East Central and South East Europe: Complex Europe (2007); Anna Grzymala-Busse, The Best Laid Plans: The Impact of Informal Rules on Formal Institutions in Transitional Regimes, 45 STUD. COMPAR. INT'L DEV. 311, 313 (2010).

${ }^{29}$ Michal Bobek, The Fortress of Judicial Independence and the Mental Transitions of the Central European Judiciaries, 14 Euro. Pub. L. 99, 107 (2008).

${ }^{30}$ James Mahoney \& Kathleen Thelen, Explaining institutional Change: Ambiguity, AgENCy, AND POWER 4 (2009).

${ }^{31}$ Douglass C. North, A Framework for Analyzing the State in Economic History, 16 ExPLORATIONs ECON. HIST. 249, 258 (1979).

${ }^{32}$ NoRTH, supra note 5 , at 61 .
} 
The implementation of principles securing the rule of law fell short due to the implementation at the outcome of the process - not at the input. Instead of transitioning towards internalizing the values of the rule of law in legal education, the focus was dedicated to the structural independence of the judiciary from other branches of government.

While the judiciary enjoyed political independence, it still maintained a system of dependencies within. Policies implemented for the transition of the judiciary did not account for patterns existing in the judiciary inherited from the past. In the following years, instead of focusing on changes in the education system and reforms towards improving mutual trust among people, it was again focused mainly on the structures hindering the possible overstepping of competencies.

In the following articles, different aspects of institutions, change, and path dependency will be explored, based on the workshop on The Breaking Point of Legal Institutions-Continuities and Discontinuities, held in Oslo in November 2019. The papers are multidisciplinary in the intersection between law, legal theory, legal history, and sociology of law. Each article employs the standard tools of legal analysis on the legal material to study the effects of communism in selected countries. Some articles analyze the concept of law and explore possible criteria for determining circumstances where the law was suspended. Some focus on empirical studies by searching for evidence of the courts on mock trials in political cases and evidence of rulings in political cases.

This Special Issue focuses primarily on how judicial institutions were affected through decisions and policies either within the judiciary or outside the judicial structure. Each article tracks the development of judicial institutions in the communist country and analyzes the remnants of this process in the current judiciaries today. At the seminar session titled Methodology and Analytical Insights Lukasz Bojarski, Peter Čuroš, Petra Gyöngyi, Lucia Berdisova, Fruzsina Gárdos-Orosz presented their Articles and provided a method for the research or analytical work with documents of courts. During the Threats to Independence of Judiciary session, James Moliterno, Pavol Žilinčík, and Matyás Bencze presented on the steps of the executive and legislative power on limiting the independence of the judiciary. Furthermore, in the Transition of the Judiciaries in the CEE session, Zoltán Szente, Ján Štiavnický, Magdalena Konopacka, and Bogdan Iancu spoke primarily on the resemblance of the policies undertaken against the judiciary in the past and nowadays. Finally, in the Paths of the Judiciaries session, Zdeněk Kühn, Zoltán Fleck, and Cosmin Cercel, offered their views on the historical process of the judiciaries within CEE countries in the previous century.

\section{Individual Contributions}

James Moliterno from Washington and Lee University and Peter Čuroš from the University of Oslo, in their article Recent Attacks On Judicial Independence: The Vulgar, The Systemic and The Insidious, offer an opening to the current situation of the CEE and attacks against the judiciary that took place in this region since 2010. They do not focus primarily on historical path dependence; instead, on the nature of attacks on the judiciary, which have appeared in the CEE countries and the US in recent years. The authors' interest lies in explaining similar patterns visible in the judiciaries of CEE. Particularly, they focus on the current conditions in the Czechia, Poland since 2015, Hungary since 2010, and the attempts for delegitimizing the judiciary in the US. The article draws on similarities of authoritarian governments' attacks and judiciaries' responses coming from a different tradition. The authors highlight similarities and diversities of the CEE countries 30 years after the fall of the communist regime and a path of these resemblances and varieties. While the rest of the articles look for footprints of the process of continuity, Moliterno and Curoš article compares different nations attacking one of the pillars of the rule of law in the U.S, Poland, Czech Republic, Hungary, and Slovakia.

Cosmin Cercel's Article Law, Politics, and the Military: Towards a Theory of Authoritarian Adjudication, focuses on the period starting in 1938 by King Carol II, followed by the dictatorship 
of General Ion Antonescu and communist takeover after WW II. This article focuses on the nexus between ideology, law, and adjudication, supported by Giorgio Agamben's and Carl Schmitt's theory of State of Exception. Cercel writes about Romania, however, pointing to similar paths judiciaries took in the Soviet Union in the 1920s through1930s and Central and Eastern Europe in the 1950s through 1960s. Cercel builds his article on the concept of crisis and ruptures with ideological consensus working in Europe since the end of the 1980s. He sees crisis-legal, political, and the crisis - under COVID-19, which caused a series of extraordinary measures coming from a government. Rather than looking for modern consequences from the communist past, Cercel compares resemblances of the interwar period with today, As he writes: "There is an uncanny resemblance that the contemporary CEE context bears with the spirit of Weimar, either in terms of jurisprudence, legal praxis, and liberal ethos." Cercel's interest lies in comparing the state of the rule of law with the state of exception. As he claims: "My interest lies in delineating within the functioning of the exception itself an unfinished process of suspension of legality, in which normative structures shift rather than disappear. "

Cercel underlines that the interwar period exhibits a turn towards a series of exceptional measures that sought to revise and reconstruct the meaning of legality within European polities. In these instances, we see a sovereign power that is resurgent within the very framework of modern legality. In his argument, Cercel draws on this shift towards overt authoritarian practices and extends his focus to other shifts from challenges to judicial independence and academic freedom to xenophobia and the questioning of legal certainty. Cercel's argument is twofold: First, he considers the law's internal inconsistency by recuperating the critical legal studies' insistence on its internal indeterminacy within the specific conditions of late capitalism. Second, he situates this foundational notion of indeterminacy both historically and conceptually within a trajectory that necessarily traces back to a specific moment of disruption within European history. Cosmin Cercel's article elaborates in detail on the concept of the state of exception. It explains the dynamics of Romania's contemporary politics and all the CEE countries in our focus. It gives the reader a comprehensive picture of the theoretical framework of the shifts within regimes.

Bogdan Iancu, an Associate Professor at the University of Bucharest, in his Article Hidden Continuities? The Avatars of 'Judicial Lustration' in Postcommunist Romania focuses on the lustration law 187/1999. Law 187/1999 was declared unconstitutional in 2008 by the Constitutional Court that contained a general where persons who had collaborated with the former communist Securitate as political police were vetted and were sanctioned for placing lustration lies in their affidavits. Iancu focuses on the hidden continuities between communist and post-communist lustration measures, declassification of Justice Ministry (SIPA) archives, and the cooperation of judicial institutions with the Romanian Intelligence Service. Continuity is visible in control mechanisms and supervision of judges. Following the Continuity and Discontinuity thesis, this article uncovers the path dependence of the institutions in Romania, in the period of the totalitarian regime, and in the transition period until today. Iancu scrutinizes legislative and constitutional judicial lustration processes against the foil of broader political-constitutional discourses. His article inquires into the context and implications of hidden continuities, actual and alleged, by comparing the year 2006 (post)communism lustration measures targeting the judiciary and the protracted discussions about the declassification of the SIPA $\operatorname{archive~}^{33}$ with the recent cooperation of judicial institutions with the Romanian Intelligence Service (Serviciul Român de Informații, SRI). This discussion is cabined in the context of the fight against corruption based on classified protocols. Iancu argues that a tradition of generalized instrumentalism links these lustration episodes. Bogdan Iancu's article contributes to the insight into SIPA archives-a topic lacking in publications. Given the minimal literature available on SIPA archives, Professor Iancu can draw on resemblances in lustration processes in the communist past, 15 years ago, and the current situation.

${ }^{33}$ SIPA was an intelligence service which functioned within the Ministry of Justice from the early 1990s until 2006. 
Zdeněk Kühn, a professor at the Charles University in Prague and a judge of the Supreme Administrative Court of the Czech Republic, contributes an article entitled Judiciary in Illiberal States. He asks how judges fail while he is looking into the decline of the Central European judiciary in the 20th century in the CEE countries. Judge Kühn deals with the actual functioning of the judicial power and the limits of its independence facing an illiberal or authoritarian state-offering a skeptical analysis of the past and especially of the future of the judiciary in Central Europe. First, Judge Kühn focuses on the historical path dependence of the institution of the modern Czech Republic and Slovakia area since the 1850s. In his historical analysis, Judge Kühn elaborates on the development of the judiciary by focusing on the independence of judges and the judiciary itself. He describes the change of the judiciary as a bureaucratic apparatus, to the independent judiciary under the emperor's patronage in Austria-Hungary, through deterioration in the interwar period, following the break of the weak judiciary during communist rule. Second, Judge Kühn investigates judicial independence from the structure of the judicial administration, where he analyzes the shift from the interwar period through state communism to the period after 1989 and its aftermath. At this point, Kühn writes on challenges for the Czech Republic after 1989. He claims that after 1989, the Czech judiciary has not faced-thus far-any substantial attack aimed against the democratic values and principles of the Czech state. It has remained far from the Polish or Hungarian scenarios of the 2010s. Third, he offers a comparative analysis of institutions of the judiciary and instruments that might be helpful to avoid an authoritarian shift and prevent the Rule of Law from backsliding-judiciary in the common law and civil (continental) law models and genuine possibilities of halting the onset of authoritarianism. As comparative law has shown in the long term, a judiciary based on the continental model of law is substantially less resistant to authoritarian regimes than a judiciary functioning in the environment of common law. Kühn seeks to explain this phenomenon. Finally, he presents possible consequences of the further shift to non-liberal democracy for the judiciary. As he claims: "If Europe enters an era of non-liberal democracy, followed by new authoritarianism, emphasis will likely be placed on, among other things, weakening the principle of checks and balances in the spirit of the populist thesis that a democratically elected political elite should not be hindered in its attempts to keep all the promises given to the voters." This Article offers an essential and original focus on the particular country-the Czech Republic-through genealogical analysis, elaboration of the current situation, and expectations for the future, coming both from a Supreme Administrative Court judge as from a university Professor.

Peter Čurošs article Panopticon of the Slovak Judiciary - Continuity of Power Centers and Mental Dependence explores the similarities between the principles guiding the judiciary today to those typical of the communist justice system, particularly the susceptibility to obedience to the requests, orders, or meeting anticipations. Čuroš claims that the habitus of the judges typical for the authoritarian regime has persisted until today and was the main reason for the judicial corruption revealed in the "Threema scandal." The article does not directly connect the judiciary's dependency to the Communist legacy embodied in members of the judiciary who served before 1989 and are active today. Still, the thesis presumes that the Communist heritage is key to understanding the current situation. The explanation is not so straightforward that. Rather than merely stating that a few individuals are considered bearers of this heritage, Čuroš argues that the past heritage is somewhat hidden in the habitus of the agents or members of the judiciary. This habitus may be unconscious yet defining for the behavior of the agents.

This article does not aim to compare the situation and actions of the judiciary members in the period of state socialism with today. The systems are so crudely different that they cannot be compared, and the judiciary's role within institutions was also fundamentally different. Instead, the article aims to identify which continuities of the judicial habitus are apparent in the current judiciary. To demonstrate changes in the position of the judiciary, this article presents a thesis of the development of the judiciary from an instrument of the governing party in maintaining a homogenous and subordinated society to the current situation of the Slovak judiciary, 
defined as a crisis of mental independence resulting in inappropriate behavior and corruption. To understand the current scandals of Slovak judges, Čuroš demonstrates the process of the shift in judicial habitus from a subservient, oppressed instrument of power to a structurally independent yet mentally dependent branch of state power.

Matyas Bencze, a professor at the Hungarian Academy of Sciences, Hungary, in his article Judicial Populism and the 'Weberian Judge' - The Strength of Judicial Resistance Against Governmental Influence in Hungary writes about the effect of judicial career systems on individual judicial independence. He focuses on the judicial career systems and the institutional design of Hungarian courts in the pre-war and socialist era. Bencze aims to show why the internal organizational model of courts and judicial ideology constitutes components of a judges' ability to resist political pressure. First, Bencze gives a quick overview of the different reactions of the Hungarian judiciary to the political pressure they have had to face since 2010. He shows that the institutional design of the Hungarian courts, formed in the pre-war and socialist era, has remained mostly unchanged up to the present day. Moreover, Bencze outlines the relationship of the institutional framework with the bureaucratic judicial mentality. After that, he explores the ideological divisions within the Hungarian judiciary seeking to explain the difference in judicial reactions. Bencze points out that the bureaucratization of the court system is not necessarily a threat to judicial independence. In his argument, Bencze claims that in the bureaucratic model, the judge inclines to please the superior-regardless, whether it is a superior court or superior body of other branches of power. Bencze also writes about the roots of the system. Before 1869, the Hungarian judiciary used to be feudalistic. It meant that different courts judged different groups, the judiciary was still a part of the administration, there was no unified procedure, no organizational law on courts, judges elected by aristocrats, and decisions were considered arbitrary.

When the transition from a feudalistic judicial system to a liberal one, the strict and bureaucratic control over judges was highly reasonable; nonetheless, it pushed the judicial self-understanding toward that of a civil servant. During state communism, the bureaucratic character became even more robust. In the 1960s, during the soft dictatorship, direct influence disappears and bureaucracy strengthened. Judges were considered to be technocrats, apolitical civil servants. After 1989, the focus was put on constitutional guarantees of judicial independence, while the internal structure of the judiciary was not a priority. The notion of the judge being conceived as a neutral bureaucrat survived. The decision-making on case-assignment, individual assessment of judges, promotion, initiation of the disciplinary procedure, and-to a certain extentsalary increases all remained within the courtleaders' competence. Bencze argues that the evaluation of judges from superiors may be one reason for strict obedience and a lack of independent thinking within the judiciary. The article offers an original argument on a particular institutional factor - the judicial career system, which forms the self-understanding of judges. It plays a vital role in both democratic as well as an authoritarian regime. Bencze builds on the inner court structure and evaluation of judges in Hungary. He claims Hungary overtook the so-called Prussian model of a judge: Well-educated bureaucrat, legal specialist, strict application of written law-which he calls the Weberian model.

Zoltán Fleck, a professor from Eötvös Loránd University in Budapest, is the author of the article with the title Changes of the Political and Legal Systems: Judicial Autonomy, in which he focuses on the relative autonomy in the judiciary under authoritarianism. Fleck's article focuses first on the the heritage of the authoritarian legal culture as the burden of the past. He focuses on the analysis of the judiciary of modern Hungary before 1918, taking a critical look at the history of Hungarian jurisprudence and elaborates on jurisprudential backwardness in modern Hungary. Fleck describes Hungarian jurisprudence as weak absolutism, where representative institutions were only instruments of noble privileges. The "constitutional question" was only defending the interests of the landowning nobles from the absolutist emperor. Even after the Austria-Hungary Compromise in 1867, the whole system was stabilized by the military, the dynasty, the bureaucracy from the Austrian side, the parliament, separation of power, and constitutional rights. 
Rechtsstaat did not play a role, according to Fleck. Second, Fleck follows the characteristics of the Communist political and legal system and how Hungary had to face autocratic legal heritage-the Soviet-Russian institutional and cultural legality after World War II. According to the socialist legal theory, after 1936, judges are independent and subordinated only to legal norms. Fleck opens the question: How could the judiciary be independent of the politics of the state and high state organs, since the unity of power - instead of separation - served the essential basis of state theory? Third, Fleck explains the judiciary before democratization. After establishing autonomy and independence, there was a battle in a different political and institutional context. However, the result remained necessarily relative. Fourth, Fleck discovers dimensions of relative judicial independence, which he portrays on the dense web of organizational bonds around the court hierarchy. Fleck argues that these bonds played a considerable role during "actually existing socialism." Fifth, Fleck moves to the resistance of judges when fighting for autonomy. After retaliation of the 1956 revolution and political amnesty, through the middle of the 1960s, political center and judiciary relations changed. There are no more direct commands, often called telephone justice or preordered judgments. The new legitimacy source became the stability and ideologyfree everyday life. The regime did not need courtrooms as a symbolic-or pedagogic-place anymore. Finally, Fleck tries to explain the dynamics of one of the vaguest concepts of socialist jurisprudence- the socialist legality, the theoretical cornerstone of the communist regimes after the Revolution of 1917. Professor Fleck's insight is crucial for his background of legal sociology and extensive previous archival work, which gives a valuable testimony on influencing judges and judicial reactions in changing political context in Hungary.

Zoltán Szente, a professor at the National University of Public Service, Budapest, in his Article Stepping Into The Same River Twice? Judicial Independence in Old and New Authoritarianism elaborates on how the new authoritarian regime systematically dismantled Western-type constitutional democracy and the rule of law while looking for resemblances in the past. Szente provides a comparison of the two periods which mirror one another with very similar characteristics. First, he focuses on the judiciary's place in the system of public bodies and constitutional standards and system's influence over the judiciary through the significant characteristics of socialist law in the post1972 period. Second, Szente puts into consideration the similarities to developments since 2010.

With respect to whether these two periods are comparable, Szente proposes two theses. First, we may presume that these two periods are not comparable even if we take the late Kádár era, a soft authoritarian regime. Hungarian socialism, however, was a Soviet-type "real" autocracy in the sphere of influence of the Soviet Union. At the same time, today, an emerging authoritarian system can only be talked about in a country which is a member of the European Union within the framework of a Western-like constitutional system. However, second, any differences are between these two periods; it is reasonable to assume that similar means are used to achieve similar goals within a closed institutional system. It is true, especially if we consider that the late Kádár era was only a moderate authoritarian regime where judicial independence was more or less recognized and realized. For Szente, there are continuities to be seen. The tools used by the old and the new authoritarian governments are plausibly comparable to each other, even if they represent two different forms and degrees of authoritarianism. He is skeptical of applying the resemblances to the socialist regime since the 1950s. Therefore, he picks only the late Kadar era and since 2010 as epochs of a declining and developing authoritarianism, respectively.

Fruzsina Gardos-Orosz, an Associate Professor at the Institute for Legal Studies, Center for Social Sciences, ELTE Law School in Budapest, is the author of the article titled Two Influential Concepts: Socialist Legality and Constitutional Identity and Their Impact on the Independence of the Judiciary. She focuses on the period of "socialism" not as a continuous development, but rather as a block divided into several stages. Gardos-Orosz focuses mainly on the period pre-1972, where she uncovers the development of institutions and path dependence in the following periods - establishing the proletarian dictatorship followed by a totalitarian dictatorship, the revolution of 1956, and the suppression after the revolution and Kádár regime. In the 
mentioned periods, she examines the change of internal and external judicial administration. Gardos-Orosz suggests considering theoretical and sociological continuities linkages between the concept and the practical use of socialist legality in Socialist Hungary ${ }^{34}$ to the concept of constitutional identity as it has developed in the Fundamental Law in Hungary. ${ }^{35}$ Gardos-Orosz begins her Article on the reforms of the Fidesz government after 2010. Between 2010 and 2012, the government gradually altered the complete judicial system. These reforms were said to focus on creating a more centralized and accountable administration of justice by establishing a more efficient and faster judicial activity. Thorough modification of the selection, the disciplinary and inaptitude proceedings was central to the judicial reform. Many of the critics of the former system complained that selection of a competent, qualified, and an independent judiciary are not appropriately regulated. Gardos-Orosz looks for similar steps towards the judiciary in the first half of the authoritarian socialist regime. She examines the change of internal and external judicial administration in the different periods of the communist-socialist regime with particular regard to the period between 1954 and 1972 and analyses the methods. The articles of Fruzsina GardosOrosz and Zoltan Szente are complementary in a way; they cover the whole period of the socialist regime in Hungary. Both articles use the period of developing authoritarianism in Hungary since 2010, but look for resemblances in different epochs of their history.

Lukasz Bojarski, PhD candidate at the University of Oslo and member of the Judges under Stress project, offers a view on the Polish case in his article Civil Society Organizations for and with the Courts and Judges - Struggle for the Rule of Law and Judicial Independence (The Case of Poland 1976-2020). Bojarski elaborates on the situation since the Polish parliamentary elections in October 2015 resulting in the takeover of the Law and Justice party's coalition and the following reforms to the judiciary. The government targeted the Constitutional Tribunal first, then the National Council of the Judiciary, the Supreme Court, and the ordinary courts. In response to subsequent moves of the government, several judges undertook various activities to defend the independence of the judiciary and judges or, more broadly, to defend the liberal democracy. An issue worth attention is the interaction and cooperation of resisting judges with other entities and their support for judicial activities. His primary focus is the role of civil society organizations (CSOs) while he takes a closer look at CSOs' activities vis-a-vis courts and judges. Bojarski claims that CSOs might play an essential role in the struggle for the rule of law and judicial independence. The role of their support for the judiciary, their struggle for independent courts, their defense of liberal values under attack might be significant, even if they seem to be underrated and underappreciated. Activities of CSOs consist of: Asking, or sometimes demanding, judges to undertake legal actions in response to state actions; communication with the public about the reasons for their decisions; and encouraging not to abdicate their positions despite political attacks. CSOs also create a public ambiance serving judicial resistance. Bojarski claims that we are witnessing an interesting phenomenon in Poland with no precedent, both when it comes to the character of the relationship between judges and CSOs and the scale and diversity of cooperation. Nevertheless, he asks: Is it an extraordinary phenomenon, born ad-hoc, or does it arise from the previous interactions between the judiciary and civil society? The Polish example shows how important the role of civil society and specialized social organizations can be in the event of a threat to the rule of law, attack on courts and their independence, and liberal democracy in general.

\footnotetext{
${ }^{34}$ With particular regard to the period following the judicial reform of 1954.

${ }^{35} \mathrm{With}$ particular regard to the period since the 2011 judicial reform.
} 